\title{
Prácticas autoevaluativas en química en el ámbito universitario
}

\author{
Ocampo, Ana B. ${ }^{1}$
}

\section{Resumen}

El presente trabajo tiene lugar en el marco de la práctica docente universitaria llevada a cabo en la Facultad de Ingeniería Química. El objetivo principal es indagar acerca de la inclusión y la mejora de prácticas autoevaluativas en la enseñanza y el aprendizaje de la Química. Se recurrió al análisis de diversas fuentes: registros observacionales, entrevistas y encuestas. Finalmente, según resultados obtenidos se proponen modalidades de trabajo a adoptar y se reflexiona sobre el rol docente.

Palabras clave: evaluación, autoevaluación, enseñanza, aprendizaje, química

\section{Summary}

This work takes place in the context of university teaching practice, held in the Faculty of Chemical Engineering. The main objective is to inquire about the inclusion and improvement of self-evaluating practices in teaching and learning of Chemistry. It was used the analysis of various sources: observational records, interviews and surveys. Finally, according to the results work arrangements are proposed to take and reflections about the role of teachers.

Keywords: evaluation, self-evaluation, teaching, learning, chemistry 